\title{
A review of material development in the field of carbon capture and the application of membrane-based processes in power plants and energy-intensive industries
}

\author{
Xuezhong He(D)
}

\begin{abstract}
This review highlights recent developments and future perspectives on $\mathrm{CO}_{2}$ capture from power plants and energyintensive industries to reduce $\mathrm{CO}_{2}$ emissions. Different types of membrane materials for $\mathrm{CO}_{2}$ capture were reviewed in terms of material performance, energy efficiency, and cost. With regard to gas separation membrane technology, only three types of membranes have been demonstrated at pilot scale. Therefore, this work paid particular attention to recent development of membrane materials such as fixed-site-carrier membranes and ultrathin nanocomposite membranes. The required high-performance membranes with $\mathrm{CO}_{2}$ permeance of $3 \mathrm{~m}^{3}(\mathrm{STP}) /$ ( $\mathrm{m}^{2} \mathrm{~h}$ bar) and high $\mathrm{CO}_{2} / \mathrm{N}_{2}$ selectivity $(>40)$ were identified as the future direction of material development. Moreover, novel energy-efficient process development for $\mathrm{CO}_{2}$ capture in power plant and process industry are discussed; the MTR patented air sweeping process is considered one of the most energy-efficient processes for post-combustion $\mathrm{CO}_{2}$ capture. In the last part, $\mathrm{CO}_{2} / \mathrm{CH}_{4}$ selectivity of $>30$ was pointed out to be the requirement of energy-efficient membrane system for $\mathrm{CO}_{2}$ removal from natural gas and biogas. Finally, significant improvements on membrane material performance, module, and process efficiency are still needed for membrane technology to be competitive in $\mathrm{CO}_{2}$ capture.
\end{abstract}

Keywords: $\mathrm{CO}_{2}$ capture, Membrane, Flue gas, Post-combustion, Natural gas, Biogas

\section{Introduction}

The International Energy Outlook [79] (IEO2011) reference case reported that world energy-related carbon dioxide $\left(\mathrm{CO}_{2}\right)$ emissions would increase to 35.2 billion metric tons in 2020 and 43.2 billion metric tons in 2035. Control of anthropogenic emissions of greenhouse gases (GHG), especially $\mathrm{CO}_{2}$, is one of the most challenging environmental issues related to global climate change. Three different solutions can be employed to reduce $\mathrm{CO}_{2}$ emissions, i.e., improving energy efficiency, switching to use less carbon-intensive and renewable energy, and carbon capture and storage (CCS). Among them, CCS is considered as one of the most promising way which can continuously use fossil fuels without causing significant increase of $\mathrm{CO}_{2}$ emissions. The main applications of CCS are likely to be at large $\mathrm{CO}_{2}$ point sources: fossil fuel

Correspondence: xuezhong.he@ntnu.no

Department of Chemical Engineering, Norwegian University of Science and Technology, N-7491 Trondheim, Norway power plants and energy-intensive industries such as iron/ steel manufacture, refinery, cement factory, and natural gas and biogas plants [1]. Among them, fossil fuel power plants are responsible for the largest $\mathrm{CO}_{2}$ emissions, and post-combustion power plants are being the main contributors which need to be firstly tackled. Moreover, $\mathrm{CO}_{2}$ removal from natural gas or biogas is also mandatory as the acid gas can cause pipeline corrosion during gas transportation. $\mathrm{CO}_{2}$ capture from exhaust gases in cement factory receives particular attention as $\mathrm{CO}_{2}$ is also a byproduct in a cement production process and cannot be avoided.

Different technologies such as chemical and physical absorption, membrane separation, physical adsorption, cryogenic distillation, and chemical looping can be used for $\mathrm{CO}_{2}$ capture in various processes [76]. The conventional chemical absorption is a mature technology for $\mathrm{CO}_{2}$ separation, but is also energy intensive and high cost, which can result in a large incremental cost and a significant 
environmental impact. Membrane technology has already been commercialized and documented as a competitive technology for selected gas separation processes such as air separation and natural gas sweetening during the last two or three decades. Great effort has been recently placed on $\mathrm{CO}_{2}$ capture using gas separation membranes, and examples are found in the literature $[16,22,27,28$, $32,33,50,77,101,127,137,158]$. However, there are still challenges on the applications of membranes for $\mathrm{CO}_{2}$ capture related to (1) the limitation of membrane separation performance (the trade-off of gas permeance and selectivity of most polymeric membranes) and (2) the poor membrane stability and short lifetime when exposing to a gas stream containing the impurities of acid gases such as $\mathrm{SO}_{2}$, $\mathrm{NO}_{\mathrm{x}}$. Thus, high-performance membranes with low material cost and high stability should be developed. MTR (Membrane Technology \& Research, Inc.) tested their high permeable ultrathin Polaris ${ }^{\mathrm{Tm}}$ membranes for $\mathrm{CO}_{2}$ capture in a 1-MW coal-fired power plant with a large pilot system. Moreover, high-performance fixed-site-carrier (FSC) membranes were developed by the NanoGLOWA project (EU FP6) for $\mathrm{CO}_{2}$ separation. A small pilot-scale system was tested in 2011 for $\mathrm{CO}_{2}$ capture from flue gas at Sines coal-fired power plant in Portugal (developed by the Membrane Research team (Memfo) at NTNU), and the stable performance over 6 months was reported [138], and their latest pilot system with $20-\mathrm{m}^{2}$ hollow fibers were tested for $\mathrm{CO}_{2}$ capture in Norcem cement factory [51]. In addition, a $10-\mathrm{m}^{2}$ PolyActive ${ }^{\circ}$ membrane module developed by Helmholtz-Zentrum Geesthacht was also tested for $\mathrm{CO}_{2}$ capture [119]. Those efforts have brought membrane technology for post-combustion $\mathrm{CO}_{2}$ capture to a higher TRL (technology readiness levels). Moreover, some emerging separation technologies based on the novel solvents of ionic liquids (high $\mathrm{CO}_{2}$ solubility) and microporous materials (solid adsorbents) of zeolite, metal organic frameworks (MOFs), and metal oxides (chemical looping cycle) have been recently developed for $\mathrm{CO}_{2}$ capture and showed a nice potential and cost reduction benefit $[17,26,67,76,95,136,162,164]$. It should be noted that those advanced materials are mostly in the early research phase, and material cost together with upscaling issue need to be further investigated. In this work, the main focus is to provide an overview of the latest development and progress of membrane materials (especially some membranes at high TRL) and membrane-based processes for $\mathrm{CO}_{2}$ capture from power plants and energy-intensive industries (e.g., cement factory, biogas, and natural gas plants).

\section{Membrane materials for $\mathrm{CO}_{2}$ capture}

Each membrane material has its own advantages and challenges related to material cost, separation performance, and lifetime. Development of advanced membrane materials to increase cost-effectiveness is crucial to bring down $\mathrm{CO}_{2}$ capture cost. Different membranes such as polymer membranes, microporous organic polymers (MOPs), FSC membranes, mixed matrix membranes (MMMs), carbon molecular sieve membranes (CMSMs), and inorganic (ceramic, metallic, zeolites) membranes can be used for $\mathrm{CO}_{2}$-related separation [76]. Each membrane material possesses its own separation property, thermal and chemical stability and mechanical strength. In general, most polymer membranes show good separation performance and relatively low cost, but a relatively low membrane stability by exposure to acid gases and adverse conditions (high temperature and pressure). Inorganic membranes can be operated in these adverse conditions, but module construction and sealing for high-temperature application are quite challenging, and production cost is usually much higher compared to polymer membranes. Novel membrane materials especially FSC and MMMs (summarized in Table 1) attract great interest in the membrane community, which are based on either an enhanced facilitated transport mechanism or combination of both polymeric and inorganic material properties. Thus, choosing a suitable membrane material for a specific application mainly depends on membrane material properties, feed gas composition and flow rate, process operating conditions, and separation requirements [123]. Recently, membrane performance has been significantly improved owning to the great effort that has been taken from the membrane community. Wang et al. [151] summarized the status of single-stage membrane performance in the upper bound plots for $\mathrm{CO}_{2} / \mathrm{N}_{2}$ and $\mathrm{CO}_{2} / \mathrm{CH}_{4}$, and most ultrathin polymer membranes stayed closer to both upper bounds compared to the commercial polymers, which indicated the great potential for carbon capture applications. It should be noted that some membranes like the MTR Polaris $^{\text {Tx }}$ membranes and the FSC membranes (patented by NTNU) have already been demonstrated at pilot scale $[51,106]$ and are quite promising for $\mathrm{CO}_{2}$ capture from flue gas due to their high performance and good stability when exposed to a flue gas containing the impurities of $\mathrm{SO}_{2}$ and $\mathrm{NO}_{\mathrm{x}}$.

\section{Polymer membranes}

Polymer membranes have been widely used for selected commercial gas separation processes due to their good separation performance, good mechanical stability, and low cost. Most membrane systems for gas separation use glassy polymers because of their high selectivity and good mechanical properties, and polyimide membranes exhibits excellent high selectivities combined with high permeances for a large variety of applications in gas separation [41], while some rubbery polymers are also used for specific vapor/gas separation processes based on gas solubility difference in membrane materials, e.g., volatile 
Table 1 Representative FSC membranes and MMMs for gas separation

\begin{tabular}{|c|c|c|c|c|}
\hline Material & Support & Membrane module & Gas separation & Reference \\
\hline \multicolumn{5}{|l|}{ FSC membranes } \\
\hline $\begin{array}{l}\text { Poly(amidoamine)/poly(vinyl } \\
\text { alcohol) }\end{array}$ & - & Flat sheet & $\mathrm{CO}_{2} / \mathrm{H}_{2}$ & [37] \\
\hline $\begin{array}{l}\text { Polyallylamine (PAAm)/poly } \\
\text { (vinyl alcohol) (PVA) blend }\end{array}$ & Polysulfone & Flat sheet & $\mathrm{CO}_{2} / \mathrm{H}_{2} / \mathrm{N}_{2} / \mathrm{CO}$ & [166] \\
\hline PVAm \& PVAm/PVA blend & $\begin{array}{l}\text { Polysulfone, polyphenylene } \\
\text { oxide (PPO) }\end{array}$ & Flat sheet, Hollow fiber & $\mathrm{CO}_{2} / \mathrm{N}_{2}, \mathrm{CO}_{2} / \mathrm{CH}_{4}$ & {$[31,71,74,86,87,147,148]$} \\
\hline \multirow[t]{2}{*}{ PVA } & - & Flat sheet & $\mathrm{CO}_{2} / \mathrm{H}_{2} / \mathrm{N}_{2}$ & [77] \\
\hline & - & Flat sheet & $\mathrm{CO}_{2} / \mathrm{CH}_{4}$ & [80] \\
\hline $\begin{array}{l}\text { CNT-reinforced PVAm/PVA } \\
\text { blend }\end{array}$ & Polysulfone & Flat sheet & $\mathrm{CO}_{2} / \mathrm{CH}_{4}$ & {$[62,63,66-69]$} \\
\hline Nanotube-reinforced PVAm & Polyethersulfone (PES) & Flat-sheet & $\mathrm{CO}_{2} / \mathrm{N}_{2}$ & [58] \\
\hline $\begin{array}{l}\text { High temperature ionic } \\
\text { liquids }\end{array}$ & Nylon & Flat sheet & $\mathrm{CO}_{2} / \mathrm{H}_{2}$ & [110] \\
\hline $\begin{array}{l}\text { Room temperature ionic } \\
\text { liquids (RTILs) }\end{array}$ & $\begin{array}{l}\text { polyvinylidene difluoride } \\
\text { (PVDF) }\end{array}$ & Flat sheet & $\begin{array}{l}\mathrm{CO}_{2} / \text { air, } \mathrm{SO}_{2} / \text { air, } \\
\mathrm{CO}_{2} / \mathrm{N}_{2} / \mathrm{H}_{2}\end{array}$ & {$[102,112]$} \\
\hline \multicolumn{5}{|l|}{ MMMs } \\
\hline Polymer matrix & Inorganic filler & Membrane module & Gas separation & Reference \\
\hline Poly(vinyl acetate) (PVAc) & Zeolite 4A, $\mathrm{TiO}_{2}$ & Flat sheet & $\mathrm{CO}_{2} / \mathrm{N}_{2}$ & {$[2-4]$} \\
\hline PIMs & ZIF-8, CNTs & Flat sheet & $\begin{array}{l}\mathrm{H}_{2} / \mathrm{N}_{2}, \mathrm{H}_{2} / \mathrm{CH}_{4}, \mathrm{He} / \mathrm{N}_{2}, \mathrm{O}_{2} / \mathrm{N}_{2} \\
\mathrm{CO}_{2} / \mathrm{CH}_{4}\end{array}$ & {$[21,82]$} \\
\hline Poly (ethylene oxide) (PEO) & Graphene oxide & Flat sheet & $\mathrm{CO}_{2} / \mathrm{N}_{2}$ & [122] \\
\hline Pebax & $\begin{array}{l}1 \mathrm{D} \text { multi-walled CNT/ } \\
\text { graphene oxide } \\
\text { nanoribbon }\end{array}$ & Flat sheet & $\mathrm{CO}_{2} / \mathrm{N}_{2}, \mathrm{CO}_{2} / \mathrm{CH}_{4}$ & [114] \\
\hline PIMs & MOFs & Flat sheet & $\mathrm{CO}_{2} / \mathrm{N}_{2}$ & [44] \\
\hline
\end{tabular}

organic compounds (VOCs) recovery and hydrocarbon recovery from natural gas. Commercial polymeric gas separation membranes are mostly made from cellulose acetate (UOP, GMS, NATCO), polysulfone (Air Products), and polyimides (Praxair), polyphenylene oxide (Parker-Hannifin), and polydimethylsiloxane (GKSS, MTR).

Gas permeability and selectivity are the two key parameters for the characterization of separation performance of dense polymer membranes, which should be as high as possible to achieve separation requirements at a low cost. However, gas permeability is mainly dependent on a thermodynamic factor (solubility $(S)$ of penetrates in a membrane) and a kinetic factor (diffusivity $(D)$ of the gas species transport through a membrane) [7]. Thus, there is a trade-off between permeability and selectivity in the dense polymer membranes as reported by Robeson [129]. The polymer membranes based on a solution-diffusion (S-D) transport mechanism cannot surpass the Robeson upper bound to achieve a higher permeability/selectivity combination unless the membranes involve other transport mechanisms such as molecular sieving and facilitated transport, or have large porosity and fractional free volume (FFV).

\section{Microporous organic polymers}

Strong interests have been put on the development of microporous organic polymers due to its large surface area. The representative MOPs include thermally rearranged (TR) polymers $[35,57,85,115,116]$ and polymers of intrinsic microporosity (PIMs) [5, 18-20, 36, 104, 144, 160]. Polyimide-based TR polymers with an average pore size 0.4-0.9 $\mathrm{nm}$ and a narrow pore size distribution was firstly prepared by Park et al. [116], which presented a molecular sieving transport mechanism for gas permeation. The flexible structures provided the feasibility and the easiness for module construction. Moreover, TR polymer membranes were also found to exhibit excellent gas separation performance for $\mathrm{CO}_{2}$-related separation processes, for examples, $\mathrm{CO}_{2} / \mathrm{CH}_{4}$ separation in high-pressure natural gas sweetening process $[35,115]$ and high temperature $\mathrm{H}_{2} / \mathrm{CO}_{2}$ separation in pre-combustion process [57]. However, most of the efforts are still focused on the development of lab-scale films of TR membranes, only a few literature reported that fabrication of hollow fiber TR membranes [84, 92, 154]. Kim et al. prepared their lab-scale TR-PBO (polybenzoxazole) hollow fiber membranes with a $\mathrm{CO}_{2}$ permeance of 1938 GPU $\left(1 \mathrm{GPU}=2.736 \times 10^{-3} \mathrm{~m}^{3}(\mathrm{STP}) /\left(\mathrm{m}^{2} \mathrm{~h} \mathrm{bar}\right)\right)[84]$, 
but the $\mathrm{CO}_{2} / \mathrm{N}_{2}$ selectivity of 13 should be further improved. Woo et al. reported a superior $\mathrm{CO}_{2}$ permeance of $\sim 2500 \mathrm{GPU}$ with a moderate $\mathrm{CO}_{2} / \mathrm{N}_{2}$ selectivity of 16 of the TR-PBO hollow fibers with ultrathin defect-free skin layer [154], which might be suitable for bulk $\mathrm{CO}_{2}$ removal from flue gas.

Another type of microporous polymer materials of PIMs attracted great interest due to their relatively slow physical aging, high gas permeability, and high selectivity compared to poly(1-trimethylsilyl-1-propyne) (PTMSP) membranes that initially formed microporous structures are rapidly corrupted [36]. PIMs showed a high surface area $\left(600-900 \mathrm{~m}^{2} /\right.$ g) as reported by Budd et al. [18] and a high fractional free volume (22-24\% [105]) which is comparable to that of PTMSP membranes (32-34.3\% [109, 120]). Du et al. reported that PIMs functionalized with $\mathrm{CO}_{2}$-philic pendant tetrazole groups (TZPIMs) can further improve $\mathrm{CO}_{2}$ permeance by increasing $\mathrm{CO}_{2}$ solubility due to the strong interaction between $\mathrm{CO}_{2}$ and $\mathrm{N}$-containing organic heterocyclic groups [36]. Their results indicated that $\mathrm{CO}_{2} / \mathrm{N}_{2}$ separation performance of TZPIMs can potentially surpass the Robeson upper bound. Moreover, a systematic review on preparation, characterization, and application of PIMs has been conducted by McKeown [104]. They pointed out that composite membranes consisting of PIMs and other polymers can present higher gas separation performance.

\section{Fixed-site-carrier membranes}

FSC membranes for $\mathrm{CO}_{2}$ separation attracted great attention due to the high $\mathrm{CO}_{2}$ permeance and selectivities of $\mathrm{CO}_{2}$ over other gas species (e.g., $\mathrm{N}_{2}$ and $\mathrm{O}_{2}$ ). The carriers (amino functional group, $-\mathrm{NH}_{2}$ ) are chemically bonded onto the polymer main chain. Thus, the FSC membranes usually present a higher stability compared to supported liquid membrane (SLM) and emulsion liquid membrane (ELM). Tong et al. conducted a review on facilitated transport membranes related to transport mechanism and materials [145]. The gas transport through a facilitated transport membrane is illustrated in Fig. 1, where the $\mathrm{CO}_{2}$ molecules react with amino functional groups when water is available, and pass through FSC membranes based on the combination of S-D and facilitated transport (FT) mechanism, while the non-reactive gas molecules (e.g., $\mathrm{N}_{2}, \mathrm{O}_{2}$ ) can only transport via S-D mechanism as documented by Kim et al. [86]. The gas permeate flux of the reactive component $A$ (such as $\mathrm{CO}_{2}$ ) will be the sum of both solution-diffusion and carrier-mediated diffusion (i.e., facilitated transport), which can be expressed as follows [86, 117]:

$$
J_{A}=\frac{D_{A}}{l}\left(c_{A, 0}-c_{A, 1}\right)+\frac{D_{A C}}{l}\left(c_{A C, 0}-c_{A C, 1}\right)
$$

where $D_{A}$ and $D_{A C}$ are diffusion coefficient of the Fickian diffusion and the carrier-mediated (complex) diffusion, respectively. $l$ is the thickness of the selective layer. Feed pressure is crucial to get high flux by enhancing the contribution from both S-D and FT. However, after the carrier saturation, further increasing feed $\mathrm{CO}_{2}$ partial pressure will not enhance the FT contribution. Thus, the trade-off between energy consumption and reduced membrane area (with increased flux) should be identified to determine the optimal operating condition [75]. A moderate feed pressure (e.g., 2.5-3 bar) was recommended as the optimal operating condition for the FSC membranes [64]. Table 1 shows some representative facilitated transport membranes that have been reported in the literature. Among them, the polyvinyl amine (PVAm)-based FSC membranes patented by the Memfo team at NTNU shows the highest $\mathrm{CO}_{2}$ permeance (up to $5 \mathrm{~m}^{3}$ (STP) $/\left(\mathrm{m}^{2} \cdot h \cdot\right.$ bar)) and $\mathrm{CO}_{2} / \mathrm{N}_{2}(>500)$ selectivity under humidified conditions [87]. This membrane is extremely promising for post-combustion $\mathrm{CO}_{2}$ capture where flue gas is usually water vapor saturated $[61,64,87]$. A pilot flat-sheet FSC membrane system has been tested in EDP's power plant in

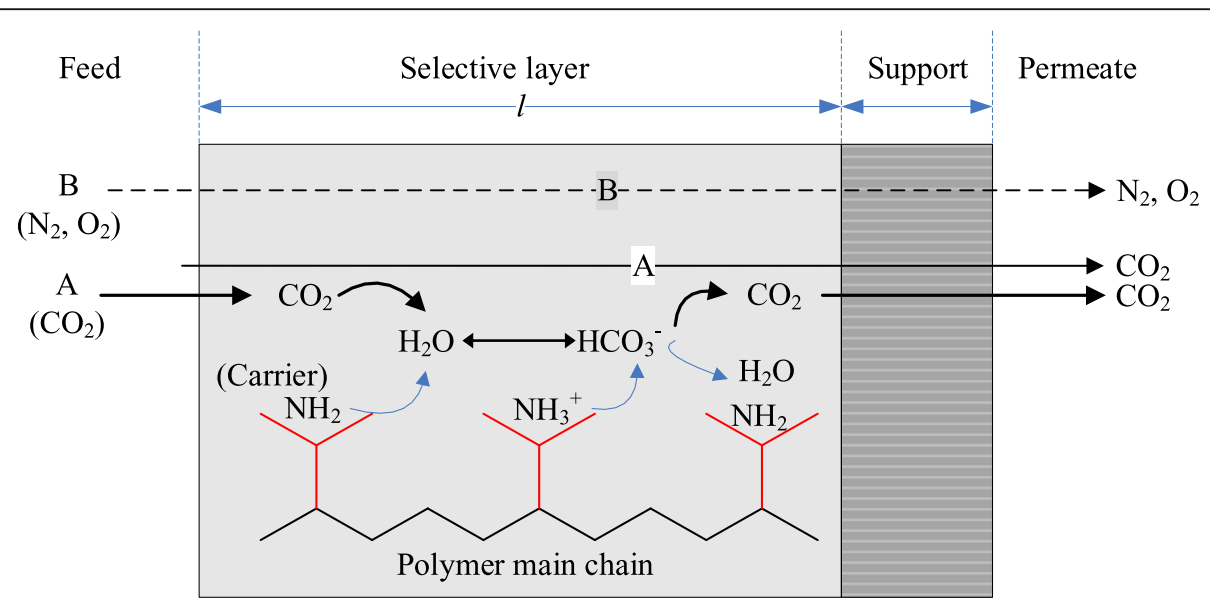

Fig. 1 The illustration of gas transport through a PVAm based FSC membrane 
Sines (Portugal) in 2011, and the membranes showed a stable performance over 6 months [52]. Later on, the hollow fiber FSC membranes were tested at Sintef $\mathrm{CO}_{2}$ lab at Tiller (Norway) with a $9.5 \% \mathrm{CO}_{2}$ contained flue gas produced from a propane burner [74]. They reported that single-stage membrane system (area $8.4 \mathrm{~m}^{2}$ ) can achieve $>60 \%$ permeate $\mathrm{CO}_{2}$ purity at a feed and permeate pressure of 2 bar and 0.2 bar, respectively, and the system also showed quite fast response when changing feed $\mathrm{CO}_{2}$ composition. The reported pilot FSC membrane system provided great flexibility on testing the influence of process operating parameters, especially temperature. However, the challenges related to the optimization of module and process should be further investigated. In addition, material development by introducing other support and more effective multi-amines and aminoacids with higher $\mathrm{CO}_{2}$ reaction kinetics and loading capacity is crucial to further improve membrane performance. Han et al. recently reported a nanotube reinforced 2-(1-piperazinyl) ethylamine sarcosinate blend with PVAm composite membrane with $1451 \mathrm{GPU} \mathrm{CO} 2$ permeance and $165 \mathrm{CO}_{2} / \mathrm{N}_{2}$ selectivity at $65{ }^{\circ} \mathrm{C}$ [58], which will be very promising if such performance can be achieved in field testing.

\section{Mixed matrix membranes}

Rigid permeable or impermeable particles are dispersed in a continuous polymeric phase to form MMMs to present interesting materials for improving separation performance of common polymer membranes [6]. Two types of inorganic fillers can be added into polymer matrix such as microporous fillers (e.g., carbon molecular sieves, zeolite) and nonporous nanoparticles (e.g., $\mathrm{SiO}_{2}, \mathrm{TiO}_{2}$ ). MMMs with microporous fillers could improve selectivity based on molecular sieving or surface flow transport mechanism, and it might also get an increased permeability if the preferred solid phase has a higher diffusion coefficient. While MMMs made by adding nonporous nanoparticles can improve gas permeability due to the increase of free volume. Chung et al. [25] reported that the properties for both polymer materials and inorganic fillers could affect the morphology and separation performance of MMMs. The rigid structure glassy polymers with high selectivity are more suitable for polymer matrix compared to rubbery polymers. However, the adhesion between glassy polymer phase and inorganic filler phase is a challenging issue for preparation of MMMs. Moreover, the thermal and chemical stabilities of MMMs are mainly dependent on physical property of a polymer matrix, which may suffer from the acid gases of $\mathrm{SO}_{2}$ or $\mathrm{NO}_{\mathrm{x}}$ that are usually involved in flue gas. MMMs normally present an enhanced mechanical strength compared to pure polymer membranes, and a reduced cost compared to pure inorganic membranes. However, the main challenge for preparation of
MMMs is to choose proper materials for both polymeric and inorganic phases to get a high gas separation performance and good compatibility. Examples for selection of polymer and inorganic filler for making $\mathrm{CO}_{2}$ selective MMMs are reviewed in the literature [76, 149], and only the latest MMM materials are listed in Table 1. Recently, the PIMs/MOF MMMs with $\mathrm{CO}_{2}$ permeance of 1740 GPU and enhanced selectivity (70\%) and mechanical strength were reported by Ghalei et al. [44]; they concluded that membranes can be further optimized for economical $\mathrm{CO}_{2}$ capture.

\section{Carbon molecular sieve membranes}

CMSMs are usually prepared by carbonization of polymeric precursors such as polyimide [10, 141, 142], polyacrylonitile (PAN) [29], poly(phthalazinone ether sulfone ketone) [163], poly(phenylene oxide) [91, 161], and cellulose derivatives $[65,68,72,73,90,99]$. CMSMs present high mechanical strength and moderate modulus due to their graphitic or turbostratic structure compared to graphitized fibers [130]. The separation mechanism of CMSMs is based on kinetic diameter difference in the gas molecules. $\mathrm{CO}_{2}$ has a smaller kinetic diameter compared to $\mathrm{O}_{2}, \mathrm{~N}_{2}$, and $\mathrm{CH}_{4}$. The hollow fiber polyimide derived carbon membranes developed by Georgia Tech have been reported for different types of gas separations (e.g., $\mathrm{CO}_{2} / \mathrm{CH}_{4}$ and olefin/paraffin [134, 135, 155]). The issues related to high precursor cost and low gas permeance need to be further addressed. The cellulose acetate (CA)-based hollow fiber carbon membranes were developed by NTNU for biogas upgrading, natural gas sweetening, and $\mathrm{H}_{2}$ separation [47, 53, 54, 97]. The main advantages of this type of carbon membrane are the low cost of CA precursor and the carbonization processability. However, it still has the challenges on (1) keeping deacetylated CA fibers straight during the drying process; (2) increasing gas permeance; and (3) reducing membrane aging due to the pore blockage of water vapor adsorption at relative humidity $(\mathrm{RH})>30 \%$.

Although CMSMs present higher production cost, more challenges on module construction (due to the relatively brittle structures), and significant aging issue compared to most polymeric membranes, the advantages of high gas permeance and selectivity as well as high thermal and chemical stability still encouraged many researchers to develop carbon membranes for gas separation [68, 72, 88, 98, 141, 146, 161]. Considering the future commercial applications, strong effort should be put on the development of high performance asymmetric hollow fiber carbon membranes or tubular ceramic supported carbon membranes. Xu et al. prepared asymmetric hollow fiber carbon membranes for olefin/paraffin and ethylene/ethane separations [156, 157]. The PVDF-based asymmetric hollow fiber carbon membranes were reported for organic liquid separations [89]. 
Their investigation results showed a promising application of carbon membranes in energy-related processes. Recently, high flux ceramic supported carbon membranes with a high $\mathrm{CO}_{2}$ permeance of $0.6 \mathrm{~m}^{3}(\mathrm{STP}) /$ $\left(\mathrm{m}^{2}\right.$.h.bar $)$ and $\mathrm{CO}_{2} / \mathrm{CH}_{4}$ selectivity of 30 were developed by Richter et al. [128], which can be potentially used for $\mathrm{CO}_{2}$ removal from natural gas. However, the membrane cost and upscaling need to be further investigated.

\section{$\mathrm{CO}_{2}$ capture from power plant}

The world fossil fuel power plants emit about two billion tons of $\mathrm{CO}_{2}$ per year which should be significantly reduced according to the Kyoto protocol. CCS is one of the most promising options for the reduction of $\mathrm{CO}_{2}$ emissions. Different techniques such as physical absorption (e.g., Selexol, Rectisol), chemical absorption (e.g., MEA, MDEA), physical adsorption (e.g., molecular sieves, metal organic frameworks), and gas separation membranes can be used to $\mathrm{CO}_{2}$ capture from flue gas in power plants. Among them, amine absorption has been widely used in for $\mathrm{CO}_{2}$ removal and considered to be the most mature technology. However, conventional amine absorption is an energy-intensive and high-cost process, which results in the large incremental costs of electricity generation. National Energy Technology Laboratory (NETL) estimated that amine unit will increase the cost of electricity production by $70 \%$ [38]. As an alternative, gas separation membranes and/or hybrid systems (e.g., membrane contactor, membrane-cryogenic process) for carbon capture, as illustrated in Fig. 2 [73], may have potentials to bring down the $\mathrm{CO}_{2}$ capture cost in this application.

\section{Gas separation membrane system}

Yang et al. reviewed the progress of $\mathrm{CO}_{2}$ separation using membrane technology, and they concluded that membrane process is energy-saving, space-saving, easy to scale-up, and can be a promising technology for $\mathrm{CO}_{2}$ separation [158]. Strong effort has been put on the development of high-performance membranes (high $\mathrm{CO}_{2}$ permeance and relatively good selectivities over other gas molecules) with good long-term stability for $\mathrm{CO}_{2}$ capture, and some ultrathin nanocomposite and FSC membranes showed great potentials $[16,17,50,70$, 77, 78, 107, 124, 139, 140, 158].

The Polaris ${ }^{\bullet}$ membranes developed by MTR has been demonstrated at pilot-scale for $\mathrm{CO}_{2}$ capture from a natural gas combined cycle power plant [23]. A 20 ton/day skid was tested to validate the advanced modules (multi-tube and plate-and-frame) designed for low-pressure drop and small footprint, and the system showed quite stable performance over ca. 1000 h [106]. Moreover, MTR patented their process by feeding high $\mathrm{CO}_{2}$ content air stream (air as sweep gas in the permeate side of the 2nd stage membrane unit) into the boiler to increase the $\mathrm{CO}_{2}$ concentration in the flue gas [9], which can greatly reduce the required membrane area and energy consumption for this application.

It is worth noting that process design is crucial to improve the overall energy efficiency of the whole process with the integration of $\mathrm{CO}_{2}$ capture unit. Many research work on technology feasibility analysis based on air sweeping process were reported. However, the influences of $\mathrm{CO}_{2}$-contained air on the boiler operation should be further tested. It is worth noting that gas permeance of Polaris membranes has been significantly improved at lab-scale. Further pilot demonstration (field testing) is required to prove the performance at larger scale.

The large EU project NanoGLOWA (including 27 partners from European companies, universities, institutes and power plants) launched in 2006 was aiming at developing high-performance membranes for $\mathrm{CO}_{2}$ capture from flue gas in post-combustion power plants. A small pilot-scale plate-and-frame module was installed in EDP's power plant in Sines (Portugal) to test the working of membranes in a real flue gas in 2011, and the membranes showed a stable performance over 6 months [52]. Recently, this type of membrane was

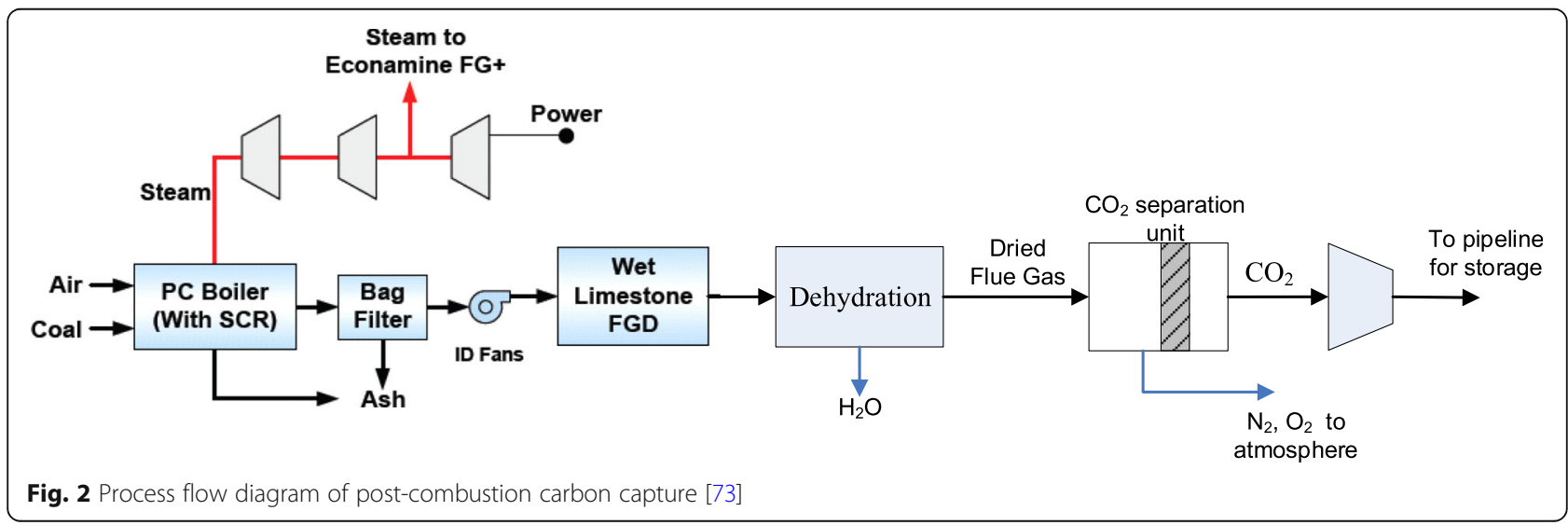


demonstrated for $\mathrm{CO}_{2}$ capture in the real flue gas from a propane burner at SINTEF Tiller plant (Trondheim, Norway) [74] and Norcem cement factory [51]. Two semi-commercial hollow fiber modules coated with PVAm selective layer (membrane area of $8.4 \mathrm{~m}^{2}$ ) were performed in parallel in a single-stage process. The testing results indicated that a $60 \mathrm{vol} \% \mathrm{CO}_{2}$ purity was achieved in the permeate stream from a feed flue gas with 9.5 vol\% $\mathrm{CO}_{2}$ [74]. In December 2016, Air Products Ltd. licensed the PVAm-based FSC membranes for post-combustion $\mathrm{CO}_{2}$ capture and will bring the technology to commercialization in the near future [48].

The PolyActive ${ }^{\mathrm{Tx}}$ membranes developed by HelmholtzZentrum Geesthacht were tested for $\mathrm{CO}_{2}$ capture from real flue gas using a pilot module with a membrane area of $12.5 \mathrm{~m}^{2}$ [119]. The membrane system also showed stable performance over $740 \mathrm{~h}$ continuously, and they also reported that membrane processes was well suitable for post combustion $\mathrm{CO}_{2}$ capture, and a $\mathrm{CO}_{2}$ purity of $68.2 \mathrm{~mol} \%$ in the permeate and a recovery of $42.7 \%$ can be achieved at the tested condition in a single-stage process. A two-stage pilot membrane system should be demonstrated to document the technology feasibility related to the energy consumption and the required membrane area. The engineering challenge on upscaling of envelop module needs to be addressed.

It should be remembered that techno-economic feasibility analysis should be conducted before bringing any type of membranes into commercial application. He et al. investigated the application of hollow fiber carbon membranes for $\mathrm{CO}_{2}$ capture from flue gas [59]. They reported a capital cost of $\$ 100 /$ tonne $\mathrm{CO}_{2}$ avoided for carbon membrane system, which was higher than a traditional chemical method of MEA (\$59/tonne $\mathrm{CO}_{2}$ avoided reported by Rao and Rubin [125]), but the referred carbon membranes had a clear potential of further optimization. Merkel et al. [107] reported that membrane with a $\mathrm{CO}_{2} / \mathrm{N}_{2}$ selectivity above 50 and a $\mathrm{CO}_{2}$ permeance of 4000 GPU could offer a capture cost below $\$ 15 /$ tonne $\mathrm{CO}_{2}$, which is lower than US Department of Energy's (DOE) target goal (\$20/tonne $\mathrm{CO}_{2}$ ). They also pointed out that improving membrane permeance is more important than increasing selectivity (if selectivity $>30$ ) to further reduce the cost of $\mathrm{CO}_{2}$ capture from flue gas [107]. He et al. [64, 70] and Hussain et al. [78] conducted process feasibility analysis by HYSYS integrated with an in-house membrane program (ChemBrane, developed by Grainger [46]) to investigate the influence of process parameters on energy demand and flue gas processing cost using a novel $\mathrm{CO}_{2}$-selective FSC membrane. Their simulation results showed that membrane process using the high-performance FSC membranes was feasible for $\mathrm{CO}_{2}$ capture to achieve $>90 \% \mathrm{CO}_{2}$ recovery and high $\mathrm{CO}_{2}$ purity above $90 \%$, even from a flue gas with a low $\mathrm{CO}_{2}$ concentration $(\sim 10 \%)$. Ramasubramanian et al. reported a $\mathrm{CO}_{2}$ capture cost of $\$ 25 /$ tonne $\mathrm{CO}_{2}$ using an assumed membrane performance of $\mathrm{CO}_{2}$ permeance of $3000 \mathrm{GPU}\left(\sim 8.2 \mathrm{~m}^{3}(\mathrm{STP}) /\left(\mathrm{m}^{2} \mathrm{~h}\right.\right.$ bar $\left.)\right)$ and $\mathrm{CO}_{2} / \mathrm{N}_{2}$ selectivity of 140 [124]. More recently, membrane properties required for post-combustion carbon capture were systematically investigated [132, 133], and a permeance of at least $3 \mathrm{~m}^{3}(\mathrm{STP}) /\left(\mathrm{m}^{2} \mathrm{~h}\right.$ bar) with high selectivity should be achieved to be competitive to MEA absorption system. Even though the required high-performance membrane has not yet been achieved, their investigations emphasized quantitatively the need of improving the present membrane performance to realize a purely membrane-based process for $\mathrm{CO}_{2}$ capture. Moreover, the $\mathrm{CO}_{2}$ capture cost for membrane system is significantly dependent on the required $\mathrm{CO}_{2}$ capture ratio. It is reported that membrane-based post-combustion $\mathrm{CO}_{2}$ capture can benefit from lower $\mathrm{CO}_{2}$ capture ratio with a 55\% cost reduction [131], and $\mathrm{CO}_{2}$ capture ratios lower than $90 \%$ would significantly improve the competitiveness of membrane-based carbon capture and lead to large cost reduction [132]. However, the overall benefit should be further investigated through the whole value chain. Therefore, the environmentally friendly technology with further improved membrane performance and properly selected process parameters and separation requirement (especially $\mathrm{CO}_{2}$ capture ratio) can be a promising candidate for post-combustion $\mathrm{CO}_{2}$ capture.

\section{Gas-liquid membrane contactor}

Membrane contactor combines the advantages of gas separation membrane technology with chemical absorption. In a membrane contactor, the membranes act as an interface between gas and liquid phase (solvent). For post-combustion $\mathrm{CO}_{2}$ capture, $\mathrm{CO}_{2}$ transports from the gas phase through microporous and hydrophobic membranes and is absorbed in the liquid phase. The $\mathrm{CO}_{2}$-loaded liquids are then pumped to the desorber to release $\mathrm{CO}_{2}$, while the regenerated solvents are recycled back to the membrane contactor [76]. This technology offers a unique way to perform gas-liquid absorption processes and provides a high operational flexibility [34]. Recently, strong interest has been focused on the efficiency studies of the membrane contactors for $\mathrm{CO}_{2}$ capture $[15,24,30,34,42,94,103,121,159]$. Yeon et al. [159] reported the use of a PVDF hollow fiber membrane contactor for absorption and a stripper column as a desorber for $\mathrm{CO}_{2} / \mathrm{N}_{2}$ separation, which presented a higher $\mathrm{CO}_{2}$ removal efficiency than the conventional absorption column. Chabanon et al. studied the wetting resistance of membrane contactors using different membrane materials, and they found that membrane contactors using composite hollow fiber membranes based on either a polymethylpentene (PMP) or a Teflon-AF thin dense layer coated on polypropylene (PP) supports showed remarkably stable performances over time compared to those of PP and polytetrafluoroethylene (PTFE) hollow fibers [24]. Feron et al. have investigated the potential application of $\mathrm{CO}_{2}$ capture 
from flues gas using a membrane contactor composed by porous polypropylene hollow fiber membranes and a dedicated absorption liquid (CORAL) [42]. Their results indicated that membrane contactor could be a promising candidate for $\mathrm{CO}_{2}$ capture from flue gases in post-combustion power plants. Moreover, Dai et al. [27, 28] reported to use ionic liquid-based membrane contactor for pre-combustion $\mathrm{CO}_{2}$ capture; the porous PTFE membrane and nonporous Teflon-PP (polypropylene) composite membranes were considered to be the most suitable membranes in this application. Even though the mass transfer resistance increases in membrane contactors particularly when membranes are wetted, the numerous advantages such as significantly increased interfacial area can potentially offset the disadvantages and makes membrane contactors to be promising in $\mathrm{CO}_{2}$ capture [165].

\section{$\mathrm{CO}_{2}$ capture from industry}

$\mathrm{CO}_{2}$ emissions from industrial sectors such as steel/iron production, cement factory, and gas production plants contribute more than $10 \%$ of total $\mathrm{CO}_{2}$ emissions. $\mathrm{CO}_{2}$ removal from natural gas and biogas is mandatory to increase methane purity and avoid pipeline corrosion. Moreover, $\mathrm{CCS}$ is the only solution to reduce $\mathrm{CO}_{2}$ emissions from cement factory as $50 \%$ of $\mathrm{CO}_{2}$ is the by-product of a cement production process. Thus, $\mathrm{CO}_{2}$ capture from those energy-intensive industries should also be implemented.

\section{$\mathrm{CO}_{2}$ removal from natural gas}

Natural gas (NG) is becoming one of the most attractive growing fuels for world primary energy consumption due to its availability and versatility. NG is a less carbon-intensive and cleaner energy source compared to the other fossil fuels of coal and crude oil. However, raw natural gas in reservoirs or/and wells usually contains considerable amount of light and heavy hydrocarbons (HHCs), as well as the impurities such as water, $\mathrm{H}_{2} \mathrm{~S}, \mathrm{CO}_{2}, \mathrm{~N}_{2}$, and helium. Natural gas sweetening is mandatory in any natural gas plants to remove the acid gases of $\mathrm{H}_{2} \mathrm{~S}$ and $\mathrm{CO}_{2}$ to meet the legal requirements and gas grid specifications. Different technologies such as chemical absorption [83], pressure swing adsorption (PSA) [81, 143], and membranes [2, 12, 43, 62, 63, 66-69, 93, 96] have been reported for $\mathrm{CO}_{2}$ removal from natural gas. Decision on which technology used for $\mathrm{CO}_{2}$ removal from natural gas is mainly dependent on process conditions and the raw natural gas composition. Conventional chemical (amine) absorption is well known and implemented in industrial processes, and still considered as the state-of-the-art technology for $\mathrm{CO}_{2}$ capture. However, membrane systems possess many advantages such as small footprint, low capital, and operating costs are environmentally friendly and exhibit their process flexibility [11], which show a great potential for natural gas sweetening even though it has only a $5 \%$ of the market today.
Commercial membranes for natural gas sweetening are usually made from cellulose acetate and polyimide and have a typical $\mathrm{CO}_{2} / \mathrm{CH}_{4}$ selectivity of $15 \sim 30$ [13]. Membrane systems are preferred for high $\mathrm{CO}_{2}$ concentration gas streams (enhanced gas recovery plant, ca. $50 \% \mathrm{CO}_{2}$, and high pressure), and amine units are preferred for relatively low-concentration gas streams. Moreover, membrane systems are also favorable to be used for processing small gas flows because of their simple flow schemes (typically in offshore platforms, $<6000 \mathrm{Nm}^{3} / \mathrm{h}$ ), while amine units are more complex and require careful, well-monitored operating procedures, as documented by Baker et al. [8]. Although common polymer membranes for natural gas sweetening are still cellulose acetate/triacetate and polyimide, the novel, high-performance FSC membranes and carbon membranes showed nice potentials for $\mathrm{CO}_{2} / \mathrm{CH}_{4}$ separation [32, 33, 55, 69].

High-pressure operation is one of the most challenging issues related to natural gas sweetening with membrane systems since membrane plasticization and compaction are found to be a well-known phenomenon in most polymer membranes [40, 152]. For the FSC membranes, carrier saturation at a high $\mathrm{CO}_{2}$ concentration or partial pressure will additionally cause the reductions of $\mathrm{CO}_{2}$ permeance and $\mathrm{CO}_{2} / \mathrm{CH}_{4}$ selectivity. The potential strategies to overcome membrane plasticization are crosslinking of membrane material [153] and fabrication of mechanical strong membranes with enhanced properties, e.g., mixed matrix membrane by adding inorganic fillers into the polymer matrix. Adams et al. prepared a $50 \%$ (vol.) Zeolite 4A/poly (vinyl acetate) MMM with increase separation performance for $\mathrm{CO}_{2} / \mathrm{CH}_{4}$ separation [2]. Their results showed a promising application for high-pressure natural gas sweetening. He et al. reported that CNTs reinforced PVAm/PVA blend FSC membrane presented a good $\mathrm{CO}_{2} / \mathrm{CH}_{4}$ separation performance at high pressure up to 40 bar [62, 63, 67-69], which showed a nice potential application for $\mathrm{CO}_{2}$ removal from natural gas. There are, however, still challenges to maintain the separation performance at higher pressure $>40$ bar (especially $>80$ bar in subsea process), which can be potentially addressed by employing high-performance (to exceed the Robeson $\mathrm{CO}_{2} / \mathrm{CH}_{4}$ upper bound) carbon membranes with high mechanical strength to tolerate high pressure without losing separation performance.

Membrane system design for $\mathrm{CO}_{2}$ removal from natural gas is mainly dependent on membrane performance, $\mathrm{CO}_{2}$ concentration in feed stream, specific separation requirement, as well as plant location. Peters et al. conducted process design, simulation, and optimization for $\mathrm{CO}_{2}$ removal from natural gas using HYSYS integrated with an in-house membrane program (ChemBrane) [118]. They reported that a two-stage membrane system 
with a $\mathrm{CO}_{2}$ permeance of $0.3 \mathrm{~m}^{3}(\mathrm{STP}) /\left(\mathrm{m}^{2} \mathrm{~h}\right.$ bar $)$ and a $\mathrm{CO}_{2} / \mathrm{CH}_{4}$ selectivity of 40 is comparable to that of amine process [118]. Although the purity of sweet gas with membrane system is a little low, it can still achieve the sales gas standards $\left(<2 \% \mathrm{CO}_{2}\right.$ in natural gas). It was also reported that two-stage membrane systems with a membrane unit cost $<\$ 60 / \mathrm{m}^{2}$ membrane area was viable for $\mathrm{CO}_{2}$ removal from a $\mathrm{CO}_{2}$ content (10 vol\%) natural gas [66]. Moreover, membrane system presents a small footprint and flexibility, and is easy to maintain, which is crucial for subsea and offshore natural gas production. It should be noted that membranes for natural gas sweetening is one of the most promising application related to the market and economic benefit.

\section{$\mathrm{CO}_{2}$ removal from biogas}

Biogas is usually produced from anaerobic digestion of wastes such as sewage sludge, animal manure, and organic fraction of household, which is mainly composed of methane $\left(\mathrm{CH}_{4}\right)$ and carbon dioxide $\left(\mathrm{CO}_{2}\right)$ and may also contain VOCs, $\mathrm{H}_{2} \mathrm{O}, \mathrm{H}_{2} \mathrm{~S}$, and $\mathrm{NH}_{3}$. Biogas has a potential of high energy due to the presence of high purity methane. However, depending on the end usage, a specific biogas treatment (i.e., biogas upgrading, defined as $\mathrm{CO}_{2}$ removal from raw biogas) should be conducted to increase the calorific value of biogas. Therefore, it is crucial to identify energy-efficient technology for $\mathrm{CO}_{2}$ removal from biogas at a low $\mathrm{CH}_{4}$ loss. The common techniques for biogas upgrading include water scrubbing, PSA, chemical absorption (e.g., amines), and gas separation membranes. The selection of suitable technology is mainly dependent on plant condition, such as the availability of low price of thermal energy, electricity and water, as well as the plant capacity. In the European region, water scrubbing is the most prevailing technology at biogas plants (40\%), and membrane has $4 \%$ of the market today [113]. Most biogas plants in Sweden are using PSA even though $\mathrm{CH}_{4}$ loss is high (3-10\%). The biogas plants using water scrubbing technology can get high purity $\mathrm{CH}_{4}(>99 \mathrm{vol} \%)$, but also produces a lot of wastewater and has high power demands. The amine scrubbing technology presents high selectivity to produce high purity methane, but the process is energy-intensive and environmentally unfriendly due to the needs of organic solvents of amines. Comparing to other state-of-the-art technologies, gas separation membrane processes present more energy- and space-saving and lower environmental impacts and are preferable for small-scale biogas plants $<1000 \mathrm{~m}^{3}(\mathrm{STP}) / \mathrm{h}$ [108]. The commercial SEPURAN ${ }^{\circ}$ membranes developed by EVONIK for biogas upgrading have low-energy requirements and low maintenance costs. The main challenge is to get high $\mathrm{CH}_{4}$ purity and low $\mathrm{CH}_{4}$ loss simultaneously. The latest reported single-stage polyimide membrane system can only reach $\mathrm{CH}_{4}$ purity of 80.7 vol\% with a high $\mathrm{CH}_{4}$ loss of $24 \%$, which is unacceptable in any biogas production plants [111]. Using a multi-stage membrane system in series can get high purity $\mathrm{CH}_{4}$, but $\mathrm{CH}_{4}$ loss will be higher. $\mathrm{A} \mathrm{CH}_{4}$ loss to atmosphere of more than $4 \%$ leads to a non-sustainable process according to carbon footprint life cycle assessment[126], which is negative related to economy and environment impact due to the high global warming potential (GWP) of methane. Therefore, seeking a high $\mathrm{CO}_{2} / \mathrm{CH}_{4}$ selective membrane (at least $>30$ ) is crucial to reduce $\mathrm{CH}_{4}$ loss, simplify process design, and reduce energy consumption. The cellulose-derived hollow fiber carbon membranes have been reported for $\mathrm{CO}_{2} / \mathrm{CH}_{4}$ separation and presented a high $\mathrm{CO}_{2} / \mathrm{CH}_{4}$ selectivity over 100 [53, 72], which showed the potential for $\mathrm{CO}_{2}$ removal from biogas. The techno-economic feasibility analysis also proved that carbon membrane can be a competitive technology for biogas upgrading compared to amine absorption [60]. Moreover, several carbon membrane modules (each one has the area of $2 \mathrm{~m}^{2}$ ) were exposed to a real biogas ( $63 \mathrm{vol} \% \mathrm{CH}_{4}, 1 \mathrm{ppm} \mathrm{H}_{2} \mathrm{~S}$, balance $\mathrm{CO}_{2}$ ) over 200 days at a biogas plant in Southern Norway. The biogas with $10 \mathrm{Nm}^{3} / \mathrm{h}$ was fed into these modules at $20 \mathrm{bar}$. A high purity methane of $96 \mathrm{vol} \%$ and a $\mathrm{CH}_{4}$ recovery of $98 \%$ was achieved [56], and the membranes showed stable performance over the testing period, which is considered at TRL 5. Although the reported pilot system can produce high purity biomethane as vehicle fuels, there are still challenges related to uniform packing of hollow fiber carbon membranes. Moreover, the brittleness of hollow fibers remained a challenge for module upscaling. Future researches should focus on improving mechanical properties and gas permeance, which directs to the development of asymmetric flexible hollow fiber carbon membranes or supported carbon membranes.

\section{$\mathrm{CO}_{2}$ capture from cement factory}

Cement factory is pursuing solutions for carbon capture from high $\mathrm{CO}_{2}$ content flue gas (ca. $17 \mathrm{vol} \%$ wet base) as it represents $7 \%$ of global anthropogenic $\mathrm{CO}_{2}$ emissions. Application of $\mathrm{CO}_{2}$ capture in cement kilns would have great potential to reduce $\mathrm{CO}_{2}$ emission from these industries but will naturally influence cement production cost. Thus, the European cement industry (through HeidelbergCement) is taking big interest in low-cost $\mathrm{CO}_{2}$ capture technologies.

Cement factory releases greenhouse gas emissions both directly and indirectly: limestone calcination directly releases $\sim 50 \%$ of all $\mathrm{CO}_{2}$ emissions in the cement production, while the burning of fuels to heat the kiln indirectly contributes another $50 \% \mathrm{CO}_{2}$ emissions. Employment of CCS is considered as one of the most important techniques to achieve the Norcem Zero $\mathrm{CO}_{2}$ Emission Vision 2030. Three different technologies (amine absorption, 
membranes, solid adsorbent) were tested on site to document the process feasibility [14]. There, the first pilot-scale membrane system using PVAm-based flat-sheet FSC membranes was tested for $\mathrm{CO}_{2}$ capture from a $17 \mathrm{vol} \%$ (wet base) $\mathrm{CO}_{2}$ flue gas in cement factory. Although many challenges related to process and module design were revealed, and it was also difficult to achieve a stable operation of membrane system, a $\mathrm{CO}_{2}$ purity up to $72 \%$ was achieved for short periods when all process parameters were well controlled in the single-stage FSC membrane system [49]. The membrane efficiency of the plate-and-frame module was quite low, and the designed system suffered significant water condensation/corrosion issues. Thus, the hollow fiber FSC membrane modules with total membrane area of ca. $20 \mathrm{~m}^{2}$ were constructed by the joint force from Air Products and Chemicals, Inc., in 2016 [51]. In that project, the pilot FSC membrane system was evaluated at TRL 5 . The system was tested over 6 months at different conditions, and stable performance was found even at a high $\mathrm{NO}_{\mathrm{x}}$ and $\mathrm{SO}_{2}$ loading (average $100 \mathrm{ppm}$ and $5 \mathrm{ppm}$, respectively) flue gas. They reported that stable permeate $\mathrm{CO}_{2}$ purity of $65 \%$ over the accumulated 24 days was achieved. The techno-economic feasibility analysis was also reported to achieve $80 \% \mathrm{CO}_{2}$ recovery and $>90 \% \mathrm{CO}_{2}$ purity. However, the designed two-stage membrane system was difficult to achieve specific $\mathrm{CO}_{2}$ purity $(>95 \%)$ requirement (especially the low $\mathrm{O}_{2}$ limitation) for enhanced oil/gas recovery (EOR/EGR). The potential solutions are to introduce a third-stage membrane unit or a low-temperature liquefaction unit. It should also be remembered that proper pre-treatment processes (e.g., particle filtering, water condensation) are always required to protect membrane system for $\mathrm{CO}_{2}$ capture in cement factory.

\section{$\mathrm{CO}_{2}$ capture from iron/steel making industry}

Recently, $\mathrm{CO}_{2}$ capture from power generation has received a lot of attention as described in the section "CO2 capture from power plant". However, only a few studies reported on $\mathrm{CO}_{2}$ capture in iron/steel manufacture industries $[39,45,100,150]$. The previous large European projects, Ultra Low $\mathrm{CO}_{2}$ Steelmaking (ULCOS) focused on the development of new steel production technology that could drastically cut $\mathrm{CO}_{2}$ emissions to $50 \%$ by the year 2030 (base year 2004), and membrane system was chosen for investigation of $\mathrm{CO}_{2}$ capture from nitrogen free blast furnace (NFBF) exhaust gases $\left(\mathrm{N}_{2} / \mathrm{CO}_{2} / \mathrm{CO} / \mathrm{H}_{2}: 10 \% / 36 \% / 47 \% / 7 \%\right)$. Lie et al. reported that PVAm/PVA blend FSC membranes can become a potential candidate for $\mathrm{CO}_{2}$ capture from flue gas in steelmaking industry with 15.0-17.5 €/tonnes $\mathrm{CO}_{2}$ [100]. Recently, Roussanaly et al. reported on the simulation of different membranes for $\mathrm{CO}_{2}$ capture from steel industry with a $30 \% \mathrm{CO}_{2}$ in feed gas, and a relatively low $\mathrm{CO}_{2}$ capture cost was identified compared to carbon capture in other processes [131]. However, it should be noted that the feed gas only contains $\mathrm{CO}_{2}$ and $\mathrm{N}_{2}$ in their study, while $\mathrm{CO}, \mathrm{H}_{2}$ are neglected which usually existed. Thus, further investigation with more accurate feed gas composition should be conducted to document the economic feasibility.

\section{Future perspectives}

The deployment of $\mathrm{CO}_{2}$ capture in power plants and process industries is crucial to reduce $\mathrm{CO}_{2}$ emissions, and several technologies should be alternatively employed depending on flue gas composition, plant location, and separation requirement. Amine absorption is still considered as the most mature technology today for large- or full-scale applications and developing next generation advanced solvents should be pursued to reduce energy consumption. Gas separation membranes, especially ultrathin polymeric and FSC membranes, for post-combustion $\mathrm{CO}_{2}$ capture were demonstrated at pilot-scale with stable performance over long-term period and considered as the most technology regarding to the environmental impact and energy efficiency. However, membrane performance should be further improved to reduce $\mathrm{CO}_{2}$ capture cost down to $\$ 20 /$ tonne $\mathrm{CO}_{2}$. Moreover, process design need to be carefully considered to make a right choice, and a two/multi-stage system is usually required to achieve high $\mathrm{CO}_{2}$ capture ratio and $\mathrm{CO}_{2}$ purity simultaneously. Nevertheless, membrane systems, which require no chemicals, are easy to scale up and have a relatively low-energy demand and could be an environmentally friendly technology for $\mathrm{CO}_{2}$ capture from power plants and other energy-intensive process industries in the future.

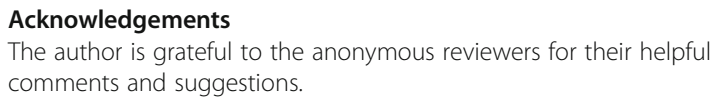

Funding

The work was supported by the CO2Hing project (\#267615) of the Research Council of Norway (Norges forskningsråd).

Availability of data and materials

Data sharing is not applicable to this article as no datasets were generated or analyzed during the current study.

Author's contribution

The author wrote, read, and approved the final manuscript.

Competing interests

The author declares that he has no competing interests.

\section{Publisher's Note}

Springer Nature remains neutral with regard to jurisdictional claims in published maps and institutional affiliations. 
Received: 23 July 2018 Accepted: 17 October 2018 Published online: 01 November 2018

\section{References}

1. Abanades JC, Akai M, Benson S, al, e., 2005. IPCC Special Report Carbon Dioxide Capture and Storage: Summary for Policymakers. http://www.ipcc. ch/pdf/special-reports/srccs/srccs_summaryforpolicymakers.pdf. Accessed 12 Sept 2018

2. Adams RT, Lee JS, Bae T-H, Ward JK, Johnson JR, Jones CW, Nair S, Koros W (2011) $\mathrm{CO}_{2}-\mathrm{CH}_{4}$ permeation in high zeolite $4 \mathrm{~A}$ loading mixed matrix membranes. J Membr Sci 367(1-2):197-203

3. Ahmad J, Hägg M-B (2013) Preparation and characterization of polyvinyl acetate/zeolite 4A mixed matrix membrane for gas separation. J Membr Sci 427(0):73-84

4. Ahmad J, Hågg MB (2013) Polyvinyl acetate/titanium dioxide nanocomposite membranes for gas separation. J Membr Sci 445:200-210

5. Ahn J, Chung W-J, Pinnau I, Song J, Du N, Robertson GP, Guiver MD (2010) Gas transport behavior of mixed-matrix membranes composed of silica nanoparticles in a polymer of intrinsic microporosity (PIM-1). J Membr Sci 346(2):280-287

6. Aroon MA, Ismail AF, Matsuura T, Montazer-Rahmati MM (2010) Performance studies of mixed matrix membranes for gas separation: a review. Sep Purif Technol 75(3):229-242

7. Baker R (2004) Membrane technology and applications, 2nd edn. McGrawHill Wiley. https://doi.org/10.1002/0470020393

8. Baker RW, Lokhandwala K (2008) Natural gas processing with membranes: an overview. Ind Eng Chem Res 47(7):2109-2121

9. Baker RW, Wijmans JG, Merkel TC, Lin H, Daniels R, Thompson S (2009) Gas separation process using membranes with permeate sweep to remove $\mathrm{CO}_{2}$ from combustion gases Membrane Technology \& Research, Inc, US

10. Barsema JN, van der Vegt NFA, Koops GH, Wessling M (2005) Agfunctionalized carbon molecular-sieve membranes based on polyelectrolyte/polyimide blend precursors. Adv Funct Mater 15(1):69-75

11. Bernardo P, Drioli E (2010) Membrane gas separation progresses for process intensification strategy in the petrochemical industry. Petrol Chem 50(4): 271-282

12. Bhide BD, Stern SA (1993) Membrane processes for the removal of acid gases from natural gas. II. Effects of operating conditions, economic parameters, and membrane properties. J Membr Sci 81(3):239-252

13. Bhide BD, Voskericyan A, Stern SA (1998) Hybrid processes for the removal of acid gases from natural gas. J Membr Sci 140(1):27-49

14. Bjerge L-M, Brevik P (2014) $\mathrm{CO}_{2}$ capture in the cement industry, Norcem $\mathrm{CO}_{2}$ capture project (Norway). Energy Procedia 63:6455-6463

15. Bottino A, Capannelli G, Comite A, Di Felice R, Firpo R (2008) $\mathrm{CO}_{2}$ removal from a gas stream by membrane contactor. Sep Purif Technol 59(1):85-90

16. Bredesen R, Jordal K, Bolland O (2004) High-temperature membranes in power generation with $\mathrm{CO}_{2}$ capture. Chem Eng Process 43(9):1129-1158

17. Brunetti A, Scura F, Barbieri G, Drioli E (2010) Membrane technologies for $\mathrm{CO}_{2}$ separation. J Membr Sci 359(1-2):115-125

18. Budd PM, Elabas ES, Ghanem BS, Makhseed S, McKeown NB, Msayib KJ Tattershall CE, Wang D (2004) Solution-processed, organophilic membrane derived from a polymer of intrinsic microporosity. Adv Mater 16(5):456-459

19. Budd PM, McKeown NB, Ghanem BS, Msayib KJ, Fritsch D, Starannikova L, Belov N, Sanfirova O, Yampolskii Y, Shantarovich V (2008) Gas permeation parameters and other physicochemical properties of a polymer of intrinsic microporosity: Polybenzodioxane PIM-1. J Membr Sci 325(2):851-860

20. Budd PM, Msayib KJ, Tattershall CE, Ghanem BS, Reynolds KJ, McKeown NB, Fritsch D (2005) Gas separation membranes from polymers of intrinsic microporosity. J Membr Sci 251(1-2):263-269

21. Bushell AF, Attfield MP, Mason CR, Budd PM, Yampolskii Y, Starannikova L, Rebrov A, Bazzarelli F, Bernardo P, Carolus Jansen J, Lanč M, Friess K, Shantarovich V, Gustov V, Isaeva V (2013) Gas permeation parameters of mixed matrix membranes based on the polymer of intrinsic microporosity PIM-1 and the zeolitic imidazolate framework ZIF-8. J Membr Sci 427(0):4862

22. Carapellucci R, Milazzo A (2003) Membrane systems for $\mathrm{CO}_{2}$ capture and their integration with gas turbine plants Proceedings of the Institution of Mechanical Engineers, Part A. J Power Energy 217(5):505-517

23. Casillas, C., Chan, K., Fulton, D., Kaschemekat, J., Kniep, J., Ly, J., Merkel, T., Nguyen, V., Sun, Z., Wang, X., Wei, X., White, S., 2015. Pilot testing of a membrane system for post-combustion $\mathrm{CO}_{2}$ capture, $\mathrm{NETL} \mathrm{CO}_{2}$ capture technology meeting Pittsburgh

24. Chabanon E, Roizard D, Favre E (2011) Membrane contactors for Postcombustion carbon dioxide capture: a comparative study of wetting resistance on long time scales. Ind Eng Chem Res 50(13):8237-8244

25. Chung T-S, Jiang LY, Li Y, Kulprathipanja S (2007) Mixed matrix membranes (MMMs) comprising organic polymers with dispersed inorganic fillers for gas separation. Prog Polym Sci 32(4):483-507

26. D'Alessandro DM, Smit B, Long JR (2010) Carbon dioxide capture: prospects for new materials. Angew Chem Int Ed 49(35):6058-6082

27. Dai $Z$, Ansaloni $L$, Deng $L$ (2016a) Precombustion $\mathrm{CO}_{2}$ capture in polymeric hollow fiber membrane contactors using ionic liquids: porous membrane versus nonporous composite membrane. Ind Eng Chem Res 55(20):5983-5992

28. Dai Z, Noble RD, Gin DL, Zhang X, Deng L (2016b) Combination of ionic liquids with membrane technology: a new approach for $\mathrm{CO}_{2}$ separation. J Membr Sci 497:1-20

29. David LIB, Ismail AF (2003) Influence of the thermastabilization process and soak time during pyrolysis process on the polyacrylonitrile carbon membranes for $\mathrm{O}_{2} / \mathrm{N}_{2}$ separation. J Membr Sci 213(1-2):285-291

30. deMontigny D, Tontiwachwuthikul P, Chakma A (2006) Using polypropylene and polytetrafluoroethylene membranes in a membrane contactor for $\mathrm{CO}_{2}$ absorption. J Membr Sci 277(1-2):99-107

31. Deng L (2009) Development of novel PVAm/PVA blend FSC membrane for $\mathrm{CO}_{2}$ capture. Norwegian University of Science and Technology, Trondheim

32. Deng L, Kim T-J, Hägg M-B (2009a) Facilitated transport of $\mathrm{CO}_{2}$ in novel PVAm/PVA blend membrane J Membr Sci 340(1-2):154-163

33. Deng L, Kim T-J, Sandru M, Hägg M-B (2009b) PVA/PVAm blend FSC membrane for natural gas sweetening. Proceedings of the 1st annual gas processing symposium, Doha, pp 247-255

34. Dindore $\mathrm{VY}$, Brilman DWF, Feron PHM, Versteeg GF (2004) $\mathrm{CO}_{2}$ absorption at elevated pressures using a hollow fiber membrane contactor. J Membr Sci 235(1-2):99-109

35. Do YS, Lee WH, Seong JG, Kim JS, Wang HH, Doherty CM, Hill AJ, Lee YM (2016) Thermally rearranged (TR) bismaleimide-based network polymers for gas separation membranes. Chem Commun 52(93):13556-13559

36. Du N, Park HB, Robertson GP, Dal-Cin MM, Visser T, Scoles L, Guiver MD (2011) Polymer nanosieve membranes for $\mathrm{CO}_{2}$-capture applications. Nat Mater 10(5):372-375

37. Duan S, Taniguchi I, Kai T, Kazama S (2012) Poly(amidoamine) dendrimer/ poly(vinyl alcohol) hybrid membranes for $\mathrm{CO}_{2}$ capture. J Membr Sci 423424(0):107-112

38. Elwell, L.C., Grant, W.S., 2006. Technology options for capturing $\mathrm{CO}_{2}$. http:// www.powermag.com/coal/Technology-options-for-capturing-CO2_582.html. Accessed 12 Sept 2018

39. Farla JC, Hendriks CA, Blok K (1995) Carbon dioxide recovery from industrial processes. Clim Chang 24:439-461

40. Favre $\mathrm{E}$ (2011) Membrane processes and postcombustion carbon dioxide capture: challenges and prospects. Chem Eng J 171(3):782-793

41. Favvas EP, Katsaros FK, Papageorgiou SK, Sapalidis AA, Mitropoulos AC (2017) A review of the latest development of polyimide based membranes for $\mathrm{CO}_{2}$ separations. React Funct Polym 120:104-130

42. Feron PHM, Jansen AE (2002) $\mathrm{CO}_{2}$ separation with polyolefin membrane contactors and dedicated absorption liquids: performances and prospects. Sep Purif Technol 27(3):231-242

43. Freeman B, Yampolskii Y (2010) Membrane gas separation. Wiley, Hoboken

44. Ghalei B, Sakurai K, Kinoshita Y, Wakimoto K, Isfahani AP, Song Q, Doitomi K, Furukawa S, Hirao H, Kusuda H, Kitagawa S, Sivaniah E (2017) Enhanced selectivity in mixed matrix membranes for $\mathrm{CO}_{2}$ capture through efficient dispersion of amine-functionalized MOF nanoparticles. Nature Energy 2:17086

45. Gielen $\mathrm{D}$ (2003) $\mathrm{CO}_{2}$ removal in the iron and steel industry. Energy Convers Manag 44(7):1027-1037

46. Grainger, D., 2007. Development of carbon membranes for hydrogen recovery, Department of Chemical Engineering Norwegian University of Science and technology, Trondheim

47. Grainger D, Hägg M-B (2007) Evaluation of cellulose-derived carbon molecular sieve membranes for hydrogen separation from light hydrocarbons. J Membr Sci 306(1-2):307-317

48. Hägg MB (2017) One step closer to bringing $\mathrm{CO}_{2}$ capture technology to the marketplace https://www.eurekalert.org/pub_releases/2017-01/nuososc011117.php. Accessed 12 Sept 2018. 
49. Hägg M-B, He X, Sarfaraz V, Sandru M, Kim T-J (2015) CO $C_{2}$ capture using a membrane pilot process at cement factory, in Brevik Norway- lessons learnt. The 8th Trondheim CCS conference (TCCS8), Trondheim

50. Hagg MB, Lindbrathen $A$ (2005) $\mathrm{CO}_{2}$ capture from natural gas fired power plants by using membrane technology. Ind Eng Chem Res 44(20):7668-7675

51. Hägg MB, Lindbråthen A, He X, Nodeland SG, Cantero T (2017) Pilot demonstration-reporting on $\mathrm{CO}_{2}$ capture from a cement plant using hollow Fiber process. Energy Procedia 114:6150-6165

52. Hägg MB, Sandru M, Kim TJ, Capala W, Huijbers M (2012) Report on pilot scale testing and further development of a facilitated transport membrane for $\mathrm{CO}_{2}$ capture from power plants. Euromembrane, London

53. Haider S, Lindbråthen A, Hägg M-B (2016) Techno-economical evaluation of membrane based biogas upgrading system: a comparison between polymeric membrane and carbon membrane technology. Green Energy Environ 1(3):222-234

54. Haider $S$, Lindbråthen A, Lie JA, Andersen ICT, Hägg M-B (2017) $\mathrm{CO}_{2}$ separation with carbon membranes in high pressure and elevated temperature applications. Sep Purif Technol 52(2):156-116

55. Haider S, Lindbråthen A, Lie JA, Andersen ICT, Hägg M-B (2018a) CO, separation with carbon membranes in high pressure and elevated temperature applications. Sep Purif Technol 190:177-189

56. Haider S, Lindbråthen A, Lie JA, Carstensen PV, Johannessen T, Hägg M-B (2018b) Vehicle fuel from biogas with carbon membranes; a comparison between simulation predictions and actual field demonstration. Green Energy Environ 3(3):266-276

57. Han SH, Kwon HJ, Kim KY, Seong JG, Park CH, Kim S, Doherty CM, Thornton AW, Hill AJ, Lozano AE, Berchtold KA, Lee YM (2012) Tuning microcavities in thermally rearranged polymer membranes for $\mathrm{CO} 2$ capture. Phys Chem Chem Phys 14(13):4365-4373

58. Han Y, Wu D, Ho WSW (2018) Nanotube-reinforced facilitated transport membrane for $\mathrm{CO}_{2} / \mathrm{N}_{2}$ separation with vacuum operation. J Membr Sci. https://doi.org/10.1016/j.memsci.2018.08.061

59. He, X., 2011. Development of hollow fiber carbon membranes for $\mathrm{CO}_{2}$ separation, Department of Chemical Engineering Norwegian University of Science and Technology, Trondheim

60. He X, Chu Y, Lindbråthen A, Hillestad M, Hägg M-B (2018) Carbon molecular sieve membranes for biogas upgrading: techno-economic feasibility analysis. J Clean Prod 194:584-593

61. He X, Fu C, Hägg M-B (2015) Membrane system design and process feasibility analysis for $\mathrm{CO}_{2}$ capture from flue gas with a fixed-site-carrier membrane. Chem Eng J 268(0):1-9

62. He X, Hägg M-B (2012c) Membranes for environmentally friendly energy processes. Membranes 2(4):706-726

63. He X, Hägg M-B (2012d) Structural, kinetic and performance characterization of hollow fiber carbon membranes. J Membr Sci 390-391(0):23-31

64. He X, Hägg M-B (2014) Energy efficient process for $\mathrm{CO}_{2}$ capture from flue gas with novel fixed-site-carrier membranes. Energy Procedia 63(0):174-185

65. He X, Hägg M-B (2011) Optimization of carbonization process for preparation of high performance hollow fiber carbon membranes. Ind Eng Chem Res 50(13):8065-8072

66. He X, Hägg M-B, Kim T-J (2014a) Hybrid FSC membrane for $\mathrm{CO}_{2}$ removal from natural gas: experimental, process simulation, and economic feasibility analysis. AIChE J 60(12):4174-4184

67. He X, Hägg MB (2012a) Hybrid fixed-site-carrier membranes for $\mathrm{CO}_{2} / \mathrm{CH}_{4}$ separation, Euromembrane 2012. UK, London

68. He X, Hägg MB (2012b) Hybrid fixed-site-carrier membranes for $\mathrm{CO}_{2} / \mathrm{CH}_{4}$ separation. Proc Eng 44(0):118-119

69. He X, Kim T-J, Hägg M-B (2014b) Hybrid fixed-site-carrier membranes for $\mathrm{CO}_{2}$ removal from high pressure natural gas: membrane optimization and process condition investigation. J Membr Sci 470(0):266-274

70. He X, Kim T-J, Hägg MB (2013) $\mathrm{CO}_{2}$ capture with membranes: process design and feasibility analysis, TCCS-7. Trondheim, Norway

71. He X, Kim T-J, Uddin MW, Hägg M-B (2013a) $\mathrm{CO}_{2}$ Removal from High Pressure Natural Gas with Hybrid Fixed-site-carrier Membranes: Membrane Material Development. AIChE Annual Meeting 2013, San Francisco

72. He X, Lie JA, Sheridan E, Hagg M-B (2011) Preparation and characterization of hollow Fiber carbon membranes from cellulose acetate precursors. Ind Eng Chem Res 50(4):2080-2087

73. He X, Lie JA, Sheridan E, Hägg M-B (2009) $\mathrm{CO}_{2}$ capture by hollow fibre carbon membranes: experiments and process simulations. Energy Procedia 1(1):261-268
74. He X, Lindbråthen A, Kim T-J, Hägg M-B (2017a) Pilot testing on fixed-sitecarrier membranes for CO2 capture from flue gas. IJGGC 64:323-332

75. He X, Nieto DR, Lindbråthen A, Hägg M-B (2017b) Membrane system design for $\mathrm{CO}_{2}$ capture, process systems and materials for $\mathrm{CO}_{2}$ capture. Wiley, pp 249-281

76. He X, Yu Q, Hägg M-B (2013b) CO 2 Capture. In: Hoek EMV, Tarabara W, editors. Encyclopedia of Membrane Science and Technology. Wiley

77. Huang J, Zou J, Ho WSW (2008) Carbon dioxide capture using a $\mathrm{CO}_{2}$-selective facilitated transport membrane. Ind Eng Chem Res 47(4):1261-1267

78. Hussain A, Hägg M-B (2010) A feasibility study of $\mathrm{CO}_{2}$ capture from flue gas by a facilitated transport membrane. J Membr Sci 359(1-2):140-148

79. International Energy Outlook 2011. https://www.iea.org/publications/ freepublications/publication/WEO2011_WEB.pdf. Accessed 30 Aug 2018.

80. Jahan Z, Niazi MBK, Hägg M-B, Gregersen ØW (2018) Cellulose nanocrystal/ PVA nanocomposite membranes for $\mathrm{CO} 2 / \mathrm{CH} 4$ separation at high pressure. J Membr Sci 554:275-281

81. Keefer, B., Doman, D., 2000. Flow regulated pressure swing adsorption system. WO/1997/039821, US

82. Khan MM, Filiz V, Bengtson G, Shishatskiy S, Rahman MM, Lillepaerg J, Abetz $\checkmark$ (2013) Enhanced gas permeability by fabricating mixed matrix membranes of functionalized multiwalled carbon nanotubes and polymers of intrinsic microporosity (PIM). J Membr Sci 436(0):109-120

83. Kidnay AJ, Parrish W (2006) Fundamentals of natural gas processing. CRC Press, Boca Raton

84. Kim S, Han SH, Lee YM (2012) Thermally rearranged (TR) polybenzoxazole hollow fiber membranes for CO2 capture. J Membr Sci 403-404(0):169-178

85. Kim S, Lee $Y$ (2012) Thermally rearranged (TR) polymer membranes with nanoengineered cavities tuned for CO2 separation. J Nanopart Res 14(7):1-11

86. Kim T-J, Li B, Hägg M-B (2004) Novel fixed-site-carrier polyvinylamine membrane for carbon dioxide capture. J Polym Sci B Polym Phys 42(23): 4326-4336

87. Kim T-J, Vrålstad H, Sandru M, Hägg M-B (2013) Separation performance of PVAm composite membrane for CO2 capture at various pH levels. J Membr Sci 428(0):218-224

88. Kiyono M, Williams PJ, Koros WJ (2010) Effect of pyrolysis atmosphere on separation performance of carbon molecular sieve membranes. J Membr Sci 359(1-2):2-10

89. Koh D-Y, McCool BA, Deckman HW, Lively RP (2016) Reverse osmosis molecular differentiation of organic liquids using carbon molecular sieve membranes. Science 353(6301):804-807

90. Koresh JE, Soffer A (1983) Molecular sieve carbon membrane part I: presentation of a new device for gas mixture separation. Separ Sci Technol 18:723-734

91. Lee H-J, Suda H, Haraya K, Moon S-H (2007) Gas permeation properties of carbon molecular sieving membranes derived from the polymer blend of polyphenylene oxide (PPO)/polyvinylpyrrolidone (PVP). J Membr Sci 296(12):139-146

92. Lee $\mathrm{S}$, Binns M, Lee JH, Moon J-H, Yeo J-g, Yeo Y-K, Lee YM, Kim J-K (2017) Membrane separation process for $\mathrm{CO} 2$ capture from mixed gases using TR and XTR hollow fiber membranes: process modeling and experiments. J Membr Sci 541:224-234

93. Li F, Li Y, Chung T-S, Kawi S (2010a) Facilitated transport by hybrid POSS ${ }^{-}$ Matrimid ${ }^{\oplus}-Z n 2+$ nanocomposite membranes for the separation of natural gas. J Membr Sci 356(1-2):14-21

94. Li J-L, Chen B-H (2005) Review of CO2 absorption using chemical solvents in hollow fiber membrane contactors. Sep Purif Technol 41(2):109-122

95. Li J, Zhang H, Gao Z, Fu J, Ao W, Dai J (2017) $\mathrm{CO}_{2}$ capture with chemical looping combustion of gaseous fuels: an overview. Energ Fuel 31(4):3475-3524

96. Li S, Carreon MA, Zhang Y, Funke HH, Noble RD, Falconer JL (2010b) Scale-up of SAPO-34 membranes for $\mathrm{CO}_{2} / \mathrm{CH}_{4}$ separation. J Membr Sci 352(1-2):7-13

97. Lie, J.A., 2005. Synthesis, performance and regeneration of carbon membranes for biogas upgrading-a future energy carrier, Department of Chemical Engineering Norwegian University of Science and technology, Trondheim

98. Lie JA, Hagg M-B (2005) Carbon membranes from cellulose and metal loaded cellulose. Carbon 43(12):2600-2607

99. Lie JA, Hagg M-B (2006) Carbon membranes from cellulose: synthesis, performance and regeneration. J Membr Sci 284(1-2):79-86

100. Lie JA, Vassbotn T, Hägg M-B, Grainger D, Kim T-J, Mejdell T (2007) Optimization of a membrane process for $\mathrm{CO}_{2}$ capture in the steelmaking industry. IJGGC 1:309-317 
101. Lin $H$, Freeman $B D$ (2005) Materials selection guidelines for membranes that remove $\mathrm{CO}_{2}$ from gas mixtures. J Mol Struct 739(1-3):57-74

102. Luis $P$, Neves LA, Afonso CAM, Coelhoso IM, Crespo JG, Garea A, Irabien A (2009) Facilitated transport of $\mathrm{CO}_{2}$ and $\mathrm{SO}_{2}$ through supported ionic liquid membranes (SILMs). Desalination 245(1-3):485-493

103. Mansourizadeh A, Ismail AF (2009) Hollow fiber gas-liquid membrane contactors for acid gas capture: a review. J Hazard Mater 171(1-3):38-53

104. McKeown NB (2012) Polymers of intrinsic microporosity. ISRN Mater Sci 2012:16

105. McKeown NB, Budd PM, Msayib KJ, Ghanem BS, Kingston HJ, Tattershall CE, Makhseed S, Reynolds KJ, Fritsch D (2005) Polymers of intrinsic microporosity (PIMs): bridging the void between microporous and polymeric materials. Chem Eur J 11(9):2610-2620

106. Merkel, T., 2016. PILOT TESTING OF A MEMBRANE SYSTEM FOR POSTCOMBUSTION $\mathrm{CO}_{2}$ CAPTURE-Final report. https://www.osti.gov/scitech/ servlets/purl/1337555. (Accessed 1 July 2018)

107. Merkel TC, Lin H, Wei X, Baker R (2010) Power plant post-combustion carbon dioxide capture: an opportunity for membranes. J Membr Sci 359(12):126-139

108. Miltner M, Makaruk A, Harasek M (2017) Review on available biogas upgrading technologies and innovations towards advanced solutions. J Clean Prod 161:1329-1337

109. Morisato A, Shen HC, Sankar SS, Freeman BD, Pinnau I, Casillas CG (1996) Polymer characterization and gas permeability of poly(1-trimethylsilyl-1propyne) [PTMSP], poly(1-phenyl-1-propyne) [PPP], and PTMSP/PPP blends. J Polym Sci B Polym Phys 34(13):2209-2222

110. Myers C, Pennline H, Luebke D, Ilconich J, Dixon JK, Maginn EJ, Brennecke JF (2008) High temperature separation of carbon dioxide/hydrogen mixtures using facilitated supported ionic liquid membranes. J Membr Sci 322(1):28-31

111. Nemestóthy N, Bakonyi P, Szentgyörgyi E, Kumar G, Nguyen DD, Chang SW, Kim S-H, Bélafi-Bakó K (2018) Evaluation of a membrane permeation system for biogas upgrading using model and real gaseous mixtures: the effect of operating conditions on separation behaviour, methane recovery and process stability. J Clean Prod 185:44-51

112. Neves LA, Nemestóthy N, Alves VD, Cserjési P, Bélafi-Bakó K, Coelhoso IM (2009) Separation of biohydrogen by supported ionic liquid membranes. Desalination 240(1-3):311-315

113. Niesner J, Jecha D, Stehlik P (2013) Biogas upgrading techniques: state of art review in european region. Chem Eng Trans 35:517-522

114. Pan X, Zhang J, Xue Q, Li X, Ding D, Zhu L, Guo T (2017) Mixed matrix membranes with excellent $\mathrm{CO}_{2}$ capture induced by Nano-carbon hybrids. ChemNanoMat 3(8):560-568

115. Park HB, Han SH, Jung CH, Lee YM, Hill AJ (2010) Thermally rearranged (TR) polymer membranes for $\mathrm{CO}_{2}$ separation. J Membr Sci 359(1-2):11-24

116. Park HB, Jung CH, Lee YM, Hill AJ, Pas SJ, Mudie ST, Van Wagner E, Freeman BD, Cookson DJ (2007) Polymers with cavities tuned for fast selective transport of small molecules and ions. Science 318(5848):254-258

117. Paul DR, Jampol'skij JP (1994) Polymeric gas separation membranes. CRC Press, Boca Raton Fla

118. Peters $L$, Hussain A, Follmann $M$, Melin T, Hägg MB (2011) $\mathrm{CO}_{2}$ removal from natural gas by employing amine absorption and membrane technology-a technical and economical analysis. Chem Eng J 172(2-3):952-960

119. Pohlmann J, Bram M, Wilkner K, Brinkmann T (2016) Pilot scale separation of $\mathrm{CO}_{2}$ from power plant flue gases by membrane technology. IJGGC 53:56-64

120. Pope DS, Koros WJ, Hopfenberg HB (1994) Sorption and dilation of poly(1(trimethylsilyl)-1-propyne) by carbon dioxide and methane. Macromolecules 27(20):5839-5844

121. Qi Z, Cussler EL (1985) Microporous hollow fibers for gas absorption I Mass transfer in the liquid. J Membr Sci 23(3):321-332

122. Quan S, Li SW, Xiao YC, Shao L (2017) $\mathrm{CO}_{2}$-selective mixed matrix membranes (MMMs) containing graphene oxide (GO) for enhancing sustainable $\mathrm{CO}_{2}$ capture. IJGGC 56:22-29

123. Ramasubramanian K, Ho WSW (2011) Recent developments on membranes for post-combustion carbon capture. Curr Opin Chem Eng 1(1):47-54

124. Ramasubramanian K, Verweij H, Winston Ho WS (2012) Membrane processes for carbon capture from coal-fired power plant flue gas: a modeling and cost study. J Membr Sci 421-422(0):299-310

125. Rao AB, Rubin ES (2002) A technical, economic, and environmental assessment of amine-based $\mathrm{CO}_{2}$ capture technology for power plant greenhouse gas control. Environ Sci Technol 36(20):4467-4475
126. Ravina M, Genon G (2015) Global and local emissions of a biogas plant considering the production of biomethane as an alternative end-use solution. J Clean Prod 102:115-126

127. Reijerkerk SR (2010) Polyether based block copolymer membranes for $\mathrm{CO}_{2}$ separation [PhD]. University of Twente, Enschede, p 245

128. Richter H, Voss H, Kaltenborn N, Kämnitz S, Wollbrink A, Feldhoff A, Caro J, Roitsch S, Voigt I (2017) High-flux carbon molecular sieve membranes for gas separation. Angew Chem Int Ed 56(27):7760-7763

129. Robeson LM (2008) The upper bound revisited. J Membr Sci 320(1-2): 390-400

130. Rodríguez-Reinoso F, Marsh H (2000) Sciences of carbon materials. Universidad de Alicante, Alicante

131. Roussanaly $\mathrm{S}$, Anantharaman $\mathrm{R}$ (2017) Cost-optimal $\mathrm{CO}_{2}$ capture ratio for membrane-based capture from different $\mathrm{CO}_{2}$ sources. Chem Eng J 327:618-628

132. Roussanaly S, Anantharaman R, Lindqvist K, Hagen B (2018) A new approach to the identification of high-potential materials for cost-efficient membrane-based post-combustion $\mathrm{CO}_{2}$ capture. Sustainable Energy Fuels 2(6):1225-1243

133. Roussanaly S, Anantharaman R, Lindqvist K, Zhai H, Rubin E (2016) Membrane properties required for post-combustion CO2 capture at coalfired power plants. J Membr Sci 511:250-264

134. Rungta M, Wenz GB, Zhang C, Xu L, Qiu W, Adams JS, Koros WJ (2017) Carbon molecular sieve structure development and membrane performance relationships. Carbon 115:237-248

135. Rungta M, Xu L, Koros WJ (2012) Carbon molecular sieve dense film membranes derived from Matrimid ${ }^{\oplus}$ for ethylene/ethane separation. Carbon 50(4):1488-1502

136. Samanta A, Zhao A, Shimizu GKH, Sarkar P, Gupta R (2011) Postcombustion $\mathrm{CO}_{2}$ capture using solid sorbents: a review. Ind Eng Chem Res 51(4):1438-1463

137. Sandru M, Haukebø SH, Hägg M-B (2010) Composite hollow fiber membranes for $\mathrm{CO}_{2}$ capture. J Membr Sci 346(1):172-186

138. Sandru M, Kim T-J, Capala W, Huijbers M, Hägg M-B (2013) Pilot scale testing of polymeric membranes for $\mathrm{CO} 2$ capture from coal fired power plants. Energy Procedia 37:6473-6480

139. Scholes CA, Ho MT, Wiley DE, Stevens GW, Kentish SE (2013) Cost competitive membrane - cryogenic post-combustion carbon capture. IJGGC 17(0):341-348

140. Shao P, Dal-Cin MM, Guiver MD, Kumar A (2013) Simulation of membrane-based $\mathrm{CO}_{2}$ capture in a coal-fired power plant. J Membr Sci 427(0):451-459

141. Steel KM, Koros WJ (2003) Investigation of porosity of carbon materials and related effects on gas separation properties. Carbon 41(2):253-266

142. Suda H, Haraya K (1997) Gas permeation through micropores of carbon molecular sieve membranes derived from Kapton polyimide. J Phys Chem B 101(20):3988-3994

143. Tagliabue M, Rizzo C, Onorati NB, Gambarotta EF, Carati A, Bazzano F (2012) Regenerability of zeolites as adsorbents for natural gas sweetening: a casestudy. Fuel 93(0):238-244

144. Thomas S, Pinnau I, Du N, Guiver MD (2009) Pure- and mixed-gas permeation properties of a microporous spirobisindane-based ladder polymer (PIM-1). J Membr Sci 333(1-2):125-131

145. Tong Z, Ho WSW (2017) Facilitated transport membranes for CO2 separation and capture. Separ Sci Technol 52(2):156-167

146. Tseng H-H, Itta AK (2012) Modification of carbon molecular sieve membrane structure by self-assisted deposition carbon segment for gas separation. J Membr Sci 389(0):223-233

147. Uddin MW, Hägg M-B (2012a) Effect of monoethylene glycol and triethylene glycol contamination on $\mathrm{CO}_{2} / \mathrm{CH}_{4}$ separation of a facilitated transport membrane for natural gas sweetening. J Membr Sci 423-424(0):150-158

148. Uddin MW, Hägg M-B (2012b) Natural gas sweetening-the effect on $\mathrm{CO}_{2}-\mathrm{CH}_{4}$ separation after exposing a facilitated transport membrane to hydrogen sulfide and higher hydrocarbons. J Membr Sci 423-424(0):143-149

149. Vinoba M, Bhagiyalakshmi M, Alqaheem Y, Alomair AA, Pérez A, Rana MS (2017) Recent progress of fillers in mixed matrix membranes for $\mathrm{CO} 2$ separation: a review. Sep Purif Technol 188:431-450

150. Wang C, Ryman C, Dahl J (2009) Potential $\mathrm{CO}_{2}$ emission reduction for BFBOF steelmaking based on optimised use of ferrous burden materials. IJGGC 3(1):29-38 
151. Wang M, Zhao J, Wang X, Liu A, Gleason KK (2017) Recent progress on submicron gas-selective polymeric membranes. J Mater Chem A 5(19):8860-8886

152. Wind JD, Paul DR, Koros WJ (2004) Natural gas permeation in polyimide membranes. J Membr Sci 228(2):227-236

153. Wind JD, Staudt-Bickel C, Paul DR, Koros WJ (2002) The effects of crosslinking chemistry on $\mathrm{CO} 2$ plasticization of polyimide gas separation membranes. Ind Eng Chem Res 41(24):6139-6148

154. Woo KT, Lee J, Dong G, Kim JS, Do YS, Hung W-S, Lee K-R, Barbieri G, Drioli E, Lee YM (2015) Fabrication of thermally rearranged (TR) polybenzoxazole hollow fiber membranes with superior $\mathrm{CO} 2 / \mathrm{N} 2$ separation performance. J Membr Sci 490:129-138

155. Xu L, Rungta M, Brayden MK, Martinez MV, Stears BA, Barbay GA, Koros WJ (2012a) Olefins-selective asymmetric carbon molecular sieve hollow fiber membranes for hybrid membrane-distillation processes for olefin/paraffin separations. J Membr Sci 423-424:314-323

156. Xu L, Rungta M, Brayden MK, Martinez MV, Stears BA, Barbay GA, Koros WJ (2012b) Olefins-selective asymmetric carbon molecular sieve hollow fiber membranes for hybrid membrane-distillation processes for olefin/paraffin separations. J Membr Sci 423-424(0):314-323

157. Xu L, Rungta M, Koros WJ (2011) Matrimid derived carbon molecular sieve hollow fiber membranes for ethylene/ethane separation. J Membr Sci 380(1-2):138-147

158. Yang H, Xu Z, Fan M, Gupta R, Slimane RB, Bland AE, Wright I (2008) Progress in carbon dioxide separation and capture: a review. J Environ Sci 20:14-27

159. Yeon S-H, Lee K-S, Sea B, Park Y-I, Lee K-H (2005) Application of pilot-scale membrane contactor hybrid system for removal of carbon dioxide from flue gas. J Membr Sci 257(1-2):156-160

160. Yong WF, Li FY, Xiao YC, Chung TS, Tong YW (2013) High performance PIM1/Matrimid hollow fiber membranes for $\mathrm{CO}_{2} / \mathrm{CH}_{4}, \mathrm{O}_{2} / \mathrm{N}_{2}$ and $\mathrm{CO}_{2} / \mathrm{N}_{2}$ separation. J Membr Sci 443(0):156-169

161. Yoshimune M, Fujiwara I, Haraya K (2007) Carbon molecular sieve membranes derived from trimethylsilyl substituted poly(phenylene oxide) for gas separation. Carbon 45(3):553-560

162. Yu C-H, Huang C-H, Tan C-S (2012) A review of $\mathrm{CO}_{2}$ capture by absorption and adsorption. Aerosol Air Qual Res 12(5):745-769

163. Zhang B, Wang T, Zhang S, Qiu J, Jian X (2006) Preparation and characterization of carbon membranes made from poly(phthalazinone ether sulfone ketone). Carbon 44(13):2764-2769

164. Zhang X, Zhang X, Dong H, Zhao Z, Zhang S, Huang Y (2012) Carbon capture with ionic liquids: overview and progress. Energy Environ Sci 5(5): 6668-6681

165. Zhao S, Feron PHM, Deng L, Favre E, Chabanon E, Yan S, Hou J, Chen V, Qi $H$ (2016) Status and progress of membrane contactors in post-combustion carbon capture: a state-of-the-art review of new developments. J Membr Sci 511:180-206

166. Zou J, Ho WSW (2006) $\mathrm{CO}_{2}$-selective polymeric membranes containing amines in crosslinked poly(vinyl alcohol). J Membr Sci 286(1-2):310-321

Ready to submit your research? Choose BMC and benefit from:

- fast, convenient online submission

- thorough peer review by experienced researchers in your field

- rapid publication on acceptance

- support for research data, including large and complex data types

- gold Open Access which fosters wider collaboration and increased citations

- maximum visibility for your research: over $100 \mathrm{M}$ website views per year

At BMC, research is always in progress.

Learn more biomedcentral.com/submissions 